\title{
An Evaluation of Guidance Services in Senior Secondary Schools in the Central Region of Ghana
}

\author{
Mary Sackey ${ }^{1}$, Josephine Anterkyi Bentil ${ }^{2}$, Alice Asiedu ${ }^{3}$ \\ ${ }^{1,2,3}$ Tutors of OLA College of Education Box 175, Cape Coast Ghana
}

\begin{abstract}
This study was conducted to find out what Guidance Service are being offered in the Senior Secondary Schools in the Central Region, their impact on students, the challenges and constrain that hinder their effective implementation. In trying to accomplish this study, related literature was reviewed. Descriptive survey was the design. Questionnaire was the main research instrument. Three sets of questionnaires were designed for students, teachers and coordinators, pilot- tested and administered to collect data. Sample sizes of 262 respondents were involved in the study. It comprised 235 SSS 2 students and 3 students, 21 tutors and 6 guidance coordinators. The sample was selected using purposive sampling and simple random sampling techniques analysis, Percentages was used. The findings of the study indicate that pupil's appraisal service, orientation service, counselling service, placement service, information service, Referral service and consultation service are being offered in the senior secondary schools. It came out that the services are appreciated by the students, and it was beneficial to students. Challenges and constraints faced include lack of office accommodation for effective guidance services, lack of funds to organized programmes and provision of in - service training for the coordinators. Recommendations include adherence to recommended teaching schedules for guidance coordinators and provision of office for the use of coordinators and for individual counselling.
\end{abstract}

\section{Keywords: Challenges, Constraints, Guidance service, Impart and Academic work.}

\section{Introduction}

A number of people, especially the youth, are known to rely on unorthodox counsellors for advice on most personal problem they have, due to lack of adequate counselling facilities. Grandparents and parent advised (and still advise) the young, for wisdom was associated with old age. Religious leaders and teachers have always played the role of counsellors by organising orientation programmes for new members of the church and group guidance for the youth. The role of native doctors, traditionally called herbalists, became accentuated as people evolved a new communal way of life and, with time, the herbalists and other traditional helpers became a source of information to the community. They also acted as advisers, predicted the future, and were highly respected by members of the community. The respect for these traditional helpers stemmed from the fact that they provided information and served as a sort of sort of comfort and succour for the confused. In some cases, they served as vocational counsellors and, in addition to this, also served as marriage counsellors to young married people within the community. Makinde, (1987).

As time went by urbanization broke family ties and so it became necessary that this wisdom be imparted to the youth in another form. Science and technology have also led to a great and rapid expansion of knowledge as such what needs to be taught in our educational institutions have become complex. Shertzer and Stone (1980) noted that industrialisation and social economics changes in society have added to the problem of human relationship. It also led to loneliness of individual in the midst of a multitude of people, where everybody is now more concerned about himself / herself than others and pays little or no attention to others. According to them, individuals have lost the touch and warmth of their fellows. A similar trend is emerging in places like Accra, Takoradi, Kumasi, Tamale and other urban towns in Ghana. 
In order to help children and youth adjust to the rapid change in the society, there arises the need for a formal type of assistance - guidance service - to be given, since the informal or the traditional mode of assistance is not able adequately provide solution to problem of children and youth. For the past forty or so years, systematic guidance has been on the educational scene in Ghana, though this had been done throughout the ages by different people in different forms at different times.

\section{Objectives of Guidance Services}

Oladele (2000) also states that guidance aims at aiding the recipient to grow in his independence and ability to be responsible. It is a service that is universal because it is not confined to the schools or the family. It is found in all phases of life - in the home, in business and industry, in government, in social life, and in hospital. Indeed, it is present where there are people who need help and wherever there are people who desire to help.

Still on the purpose of guidance services, Makinde (1983) and Sharma and Okon (1978), cited in Kankam and Onivehu (2000) enumerated the following among others as the objectives for which a school guidance programme is necessary.

To assist all students to make appropriate, satisfying, personal, social, educational and vocational choices.

$>$ To develop among students, planning skills through the understanding of personal decision - making and coping skills to adapt to different situation

$>$ To help students identify the procedures involved in advancing from secondary schools to the world of work or higher institution.

Archer (1989) contends that for guidance to achieve its suggested and acclaimed goals, the services involved must be well organised and structured. Archer and several other authorities are in agreement with conceptualising guidance to comprise of orientation, consultation, information, counselling, appraisal, placement, follow - up, and evaluation services. Bedu - Addo (2002) states that, guidance service are those services that help in achieving the goals that guidance sets itself to achieve. He continued by saying that without those services, guidance, as it were, would not have the cutting edge to give a helping hand to the individual who seeks help. Guidance service therefore, provide the youth with basic knowledge and opportunity to learn more about their environment and themselves and any sort of guidance that fails in this direction. From the internet, guidance services are said to provide coordination, development, implementation, and administration of appropriate state - wide activities that support comprehensive guidance programmes in schools.

(http:/www.poly.edu/counselling/services/index.php.)

Bedu - Addo (2002) notes the aim of guidance is preparing the individual for a better future; hence the trainee must be up - to - date and futuristic. The information may be classified in such a way that the trainee would be able to understand and use it in the future. This will help guidance fulfil its preventive role. He also stated that guidance and counselling help the individual to cope with changes that will inevitably come their way. Such changes include social, economic, environmental and industrial changes. The findings of the studies conducted by Awabil (1996) in the Upper East Region, Abukari (1996) in Tamale Municipality, and Adusei - Poku (1996) in the Greater Accra Region on Evaluation of guidance Services indicated that students realised the usefulness and need for guidance services in their schools. Globally, guidance services are meant to prepare students for adult life as well as help them acquire appropriate lifelong attitudes and values that enable them to become productive and active members of their communities. Therefore, the purpose of the study was to Evaluation of Guidance Services in Senior Secondary Schools in the Central Region of Ghana.

\section{Research questions}

1. What guidance services are currently being provided in senior secondary schools?

2. What impact has the provision of guidance service made on student' academic performance?

3. What are the constraints and challenges to the provision of guidance service in senior secondary schools?

\section{Methodology}


The researchers adopted the descriptive survey design for the study. Some writers, including Fraenkel $\&$ Wallen (2000) and Gay (1992), point out that a descriptive survey allows the the researcher to collect data through the use of questionnaire, interview or ability test. Again, Fraenkel et al (1990) state that obtaining answers from a large group of people to a set of carefully designed and administration questionnaire lies at the heart of survey research. I used the survey because I was interested in the opinion of a large group of people about the topic of Evaluation of Guidance Services in Senior Secondary Schools in the Central Region.

The study was carried out in the Senior Secondary Schools in the Central Region of Ghana. The target population for the study was all the students in senior secondary schools in the Central Region where guidance services are provided. Specifically, the subjects chosen for the study were students in SHS2 and SHS 3. Students in SHS 2 and SHS 3 were chosen because they have been in the school for, at least one year and they must have some ideas about the guidance service that are available and in use in the school and they were considering their choices of careers and selection of higher institution. The researcher collected data for the study from six senior secondary schools in the Central Region. Three groups of respondents were used for the study. The respondents were students, tutor and guidance coordinators. This was to enable the researcher have a fair representation of the stakeholders in the school. Forty (40) students were sampled from each senior secondary schools, made up of twenty (20) SHS 2 and twenty (20) SHS 3. Four Tutors, and the guidance coordinator were also sampled from each senior secondary schools.

The sampled schools were chosen using purposive sampling procedure whereby the researcher handpicks the cases to be included in his sample, on the basis of his judgement of their speciality and typicality (Cohen \& Manion, 1991) $\quad$ p. 69). The lottery method was used. The schools comprised of two boys' schools, two girl's school and two mixed sex schools. The selected schools are Mfantsiman Girls Secondary School, Saltpond, Holy Child School, Mfantsipim School, Adisadel College, (all in Cape Coast) Swedru Secondary schools and Apam Secondary. To ensure fair and equitable representation of the group and sexes, a sample size of two hundred and seventy (270) made up of two hundred and forty (240) students, that is one hundred and twenty (120) males and one hundred and twenty (120) females, twenty four (24) tutors and six (6) guidance coordinators of the sample schools were also involved in the study.

The main instrument for collecting data for the study was the questionnaire. Cohen and Manion (1991) state that, questionnaire as an instrument tends to be more reliable, while its anonymity encourages a greater degree of honesty.

The researcher prepared three sets of questionnaire. Each set of questionnaires comprised a combination of both open ended and closed- ended items to enable the researcher obtain as much detailed information as possible from the respondents. The closed - ended items had options from which respondents could choose those that apply in the schools. The open - ended items did not have pre - determined set of responses and thus the respondents was at liberty to supply the information he or she deemed fit. The close - ended items, apart from reducing completion time, also make it easier for data analysis and processing. Thus, the open ended items were to ensure wider variety of response that reflects opinion of respondents. Fraenkel and Wallen (2000) state that open - ended items allow more freedom of response, they are easy to construct and permit follow - up by the researcher.

The questionnaire for students was divided into two main parts. The first part was designed to solicit some personal data from the respondents such as the name, of the institution, level and gender. The second part included seven close - ended items (which allowed limited responses) and one open -ended form, (which permitted any response in the respondent's own words). The second part of the questionnaire was concerned with finding out the guidance services that are available and provided in the senior secondary schools, their impact on students' academic performance and the challenges and constraints the programme is facing.

Another set of questionnaire was designed for Tutors which was also divided into two parts. The first part solicit personal data, name of institution, sex, highest qualification and rank in GES the second par included 10 closed -ended items and one open - ended form. The first part of coordinators questionnaire is no exception from the tutors. The second part consists of seven close - ended items and one open - ended forms. Both tutors and coordinators questionnaire solicit the same information as that of students. 


\section{Discussion}

Descriptive statistics were primarily used for the analysis. The data obtained were computed and analysed, using percentages and frequencies. The data analysis was aided by the use of the data analysis programme known as the Statistical Package for the Social Sciences (SPSS). In the analysis of data, responses given by respondent were tallied, frequencies noted and the frequency distribution table prepared with the responses obtained. Frequencies obtained for the responses for each item and/ or option was converted into percentages in order to determine the different responses given by specific proportion of the study sample.

With the close -ended questionnaire items, the researcher coded and entered them into the computer using the SPSS software programme. The result that were obtained (as data output) from the SPSS were analysed and interpreted to describe the issues of Guidance Service in the senior secondary schools in the Central Region of Ghana. Since open - ended items cannot be easily coded (Creswell, 2003) similar responses to the items were grouped together (according to common ideas expressed by respondents). The established category of responses (obtained from common ideas) was coded and fed into the computer for analysis, interpretation and description.

Table 1 : A distributive table showing the kind of guidance services that are provided

\begin{tabular}{|c|c|c|c|c|}
\hline Respondents & Guidance services & Responses & Frequency & Percentage \\
\hline \multirow[t]{4}{*}{ Students } & \multirow[t]{4}{*}{ Appraisal services } & Yes & 117 & 49.8 \\
\hline & & No & 106 & 45.1 \\
\hline & & No response & 12 & 5.1 \\
\hline & & Total & 235 & 100 \\
\hline \multirow{4}{*}{ Students } & \multirow{4}{*}{ Information services } & Yes & 141 & 60.0 \\
\hline & & No & 82 & 34.9 \\
\hline & & No response & 12 & 5.1 \\
\hline & & Total & 235 & 100 \\
\hline \multirow{4}{*}{ Students } & \multirow[t]{4}{*}{ Placement services } & Yes & 129 & 54.9 \\
\hline & & No & 94 & 40.0 \\
\hline & & No response & 12 & 5.1 \\
\hline & & Total & 235 & 100 \\
\hline \multirow[t]{4}{*}{ Students } & \multirow[t]{4}{*}{ Consultation services } & Yes & 121 & 51.5 \\
\hline & & No & 102 & 43.4 \\
\hline & & No response & 12 & 5.1 \\
\hline & & Total & 235 & 100 \\
\hline \multirow[t]{4}{*}{ Students } & \multirow[t]{4}{*}{ Counselling services } & Yes & 193 & 82.1 \\
\hline & & No & 29 & 12.8 \\
\hline & & No response & 12 & 5.1 \\
\hline & & Total & 235 & 100 \\
\hline \multirow[t]{4}{*}{ Students } & \multirow[t]{4}{*}{ Orientation services } & Yes & 178 & 75.7 \\
\hline & & No & 45 & 19.1 \\
\hline & & No response & 12 & 5.1 \\
\hline & & Total & 235 & 100 \\
\hline
\end{tabular}




\begin{tabular}{|c|c|c|c|c|}
\hline \multirow{4}{*}{ Students } & \multirow{4}{*}{ Evaluation service } & Yes & 79 & 33.6 \\
\hline & & No & 144 & 61.3 \\
\hline & & No response & 12 & 5.1 \\
\hline & & Total & 235 & 100 \\
\hline \multirow{4}{*}{ Tutors } & \multirow{4}{*}{ Appraisal service } & Yes & 16 & 76.2 \\
\hline & & No & 5 & 23.8 \\
\hline & & No response & - & - \\
\hline & & Total & 21 & 100 \\
\hline \multirow{4}{*}{ Tutors } & \multirow{4}{*}{ Information service } & Yes & 17 & 81.0 \\
\hline & & No & 4 & 19.0 \\
\hline & & No response & - & - \\
\hline & & Total & 21 & 100 \\
\hline \multirow{4}{*}{ Tutors } & \multirow{4}{*}{ Placement service } & Yes & 17 & 81.0 \\
\hline & & No & 4 & 19.0 \\
\hline & & No response & - & - \\
\hline & & Total & 21 & 100 \\
\hline \multirow{4}{*}{ Tutors } & \multirow{4}{*}{ Consultation service } & Yes & 8 & 38.1 \\
\hline & & No & 13 & 61.9 \\
\hline & & No response & - & - \\
\hline & & Total & 21 & 100 \\
\hline \multirow[t]{4}{*}{ Tutors } & \multirow{4}{*}{ Counselling service } & Yes & 21 & 100 \\
\hline & & No & - & - \\
\hline & & No response & - & - \\
\hline & & Total & 21 & 100 \\
\hline \multirow{4}{*}{ Tutors } & \multirow{4}{*}{ Orientation service } & Yes & 18 & 85.7 \\
\hline & & No & 3 & 14.3 \\
\hline & & No response & - & - \\
\hline & & Total & 21 & 100 \\
\hline \multirow{5}{*}{ Tutors } & \multirow{5}{*}{ Evaluation service } & Yes & 7 & 33.3 \\
\hline & & No & 13 & 61.9 \\
\hline & & No response & 1 & 4.8 \\
\hline & & Total & 21 & 100 \\
\hline & & Yes & 5 & 83.3 \\
\hline \multirow[t]{3}{*}{ coordinators } & \multirow{3}{*}{ Appraisal service } & No & 1 & 16.7 \\
\hline & & No response & - & - \\
\hline & & Total & 6 & 100 \\
\hline \multirow{4}{*}{ coordinators } & \multirow{4}{*}{ Information service } & Yes & 5 & 83.3 \\
\hline & & No & 1 & 16.7 \\
\hline & & No response & - & - \\
\hline & & Total & 6 & 100 \\
\hline \multirow[b]{4}{*}{ coordinators } & & Yes & 5 & 83.3 \\
\hline & Placement service & $\mathrm{No}$ & 1 & 16.7 \\
\hline & & No response & - & - \\
\hline & & Total & 6 & 100 \\
\hline & & Yes & 5 & 83.3 \\
\hline & Consultation service & No & 1 & 16.7 \\
\hline coordinators & & No response & - & - \\
\hline & & Total & 6 & 100 \\
\hline & Counselling service & Yes & 6 & 100 \\
\hline coordinators & & No & - & - \\
\hline & & No response & - & - \\
\hline
\end{tabular}




\begin{tabular}{|l|l|l|l|l|}
\cline { 3 - 5 } & & Total & $\mathbf{6}$ & $\mathbf{1 0 0}$ \\
\hline \multirow{3}{*}{ coordinators } & \multirow{2}{*}{ Orientation service } & Yes & 6 & 100 \\
\cline { 3 - 5 } & & No & - & - \\
\cline { 3 - 5 } & & No response & - & - \\
\cline { 3 - 5 } & & Total & $\mathbf{6}$ & $\mathbf{1 0 0}$ \\
\hline \multirow{3}{*}{ coordinators } & \multirow{3}{*}{ Evaluation service } & Yes & 5 & 83.3 \\
\cline { 3 - 5 } & & No & 1 & 16.7 \\
\cline { 3 - 5 } & & No response & - & - \\
\cline { 3 - 5 } & & Total & $\mathbf{6}$ & $\mathbf{1 0 0}$ \\
\hline
\end{tabular}

Source: Field data, Sackey, Bentil and Asiedu (2018)

The table above indicates that about $50 \%$ of the students responded "Yes" while $45 \%$ responded "No" to the question on provision of appraisal service. $76 \%$ of tutors stated that appraisal service is provided for students in the schools. However, $24 \%$ of the tutors responded in the negative. $83 \%$ of the coordinators responded positively to the question, of provision of guidance services while $17 \%$ of the coordinators responded in the negative. The response given by all respondents showed that pupils Appraisal service is provided in the senior secondary in the Central Region. Responses by students, (50\%), tutors (76\%) and coordinators (83\%) show an encouraging provision level.

The results are consistent with that of Ngama (1990) and Numale (2003) who found out that the appraisal service to large extent was being rendered to students. It also confirmed Assoah's (2004) finding that appraisal service is frequently delivered in the schools. All the schools covered in the research have students' personal file or cumulative records folders which contain data on the students. The researcher had also expected a higher positive response from the student respondent than it turned out to be. But from explanations given when the researcher interacted with some of the students, it came out that the records were being kept by the administration and released only on referral of students to the guidance coordinators. Consequently, some members of staff that is tutors did not know much about the contents. The manner of keeping the cumulative records folder at the administration is not completely out of place since some of the data contained in them should be kept in confidence (Ipaye 1983) and made available to guidance personnel and those teachers who needs to report on some students in the school. (Okoye, Adejumo\& Achebe1990). I hold the view that in a properly organised guidance services, the administration and guidance office should keep independent records on students. However, one would have expected that if there was proper coordination the coordinators would have briefed all members of staff on aspects of the cumulative record folders, especially the academic performance. Staff, could then have access and contribute in confidence to the solution through the guidance coordinator. As things stand, it appears that some teaching staff are not much concerned about the personal progress of their students. The students' responses showed that majority of them were aware that records were being kept about them. However, students' responses were split between "Yes" and "No". The split might have occurred because students were either unaware or unsure of what appraisal service was. It is also possible that those who responded "No" might be those who had not had any personal counselling sessions with the guidance coordinator when this record could be referred to. What should be noted is that it is through the appraisal service that the guidance coordinators can help the students gain a better understanding of themselves (Kowitz and Kowitz, 1971. Cited in Ipaye 1983).

Again, on provision of information service shows $60 \%$ of the student's respondents responded "Yes" to the item on availability of information service while $35 \%$ said "No" to the information service rendered in the school. The responses of the tutors on information service indicate that $81 \%$ of tutors responded "Yes" to the provision of the service.

It was observed that, $83 \%$ of the coordinators, responded that information service was provided in their schools.

The data indicates that majority of all respondents stated that information service was available in their schools. The data agree with Numale (2003), that information service is available in the schools.

On the path of placement service $55 \%$ of students indicated that placement service was provided "while $40 \%$ said it was not. Eighty one percent of tutors responded that placement service was available. The data 
collected from coordinators also reveal that $83 \%$ of the coordinators responded "Yes" to the availability of placement service. The findings in respect of the placement service are consistent with that of Ngama (1990) which showed that the placement service was being rendered to students and Numale (2003) that placement service in the senior secondary schools in available. The present study contradicts the observation of Essuman (2001) that placement service was rarely provided in schools.

The response from the students indicated that $52 \%$ said yes to consultation service while $43 \%$ said No. The Tutors responses reveal that $38 \%$ of tutors responded yes while $62 \%$ responded No. In the case of coordinators $83 \%$ indicated positive responses and $17 \%$ indicated a negative response. The result from the students and coordinators show that consultation service was being provided. Surprisingly, however, the tutors' responses showed that consultation service was not available. The reason for this disparity between the responses of student and coordinators on one side and tutors on the other hand is that, perhaps, parents of students were consulting the guidance coordinators more than other members of staff on problems affecting the students, and the students were aware of it. Since the issues usually revolves round the students, it stand to reason that students may be much more aware of what is going on than anybody else. Since this may, in many cases, be individualized, it may not be strange for tutors to hold contrary views. This is possible, especially, if the matter at the centre of the consultation is private and confidential, which the case in counselling is. The study found out that guidance coordinators were consulting parents more than tutors which is in line with the objectives of consultation. The result of the study confirms Ocansey's (1992) assertion that consultation with parents constituted the major activity. The result of the present study portray that consultation service was being provided and was consistent with Amenyedzi (1997) and Adusei - Poku (1996) who reported that consultation service was being offered in the schools.

The data on the provision of Counselling service indicates that $82 \%$ of the students responded "Yes" while $13 \%$ said "No" to the provision of counselling service in the school. The tutors and coordinators responses also confirmed that counselling is being given to students since $100 \%$ in each case respond "Yes" to provision of counselling.

The data show that, for the first time all categories of respondents were near unanimous that counselling was provided in the schools. The findings in respect of the provision of counselling service corroborate that of Ngama (1990). In Ngama's study both tutors and students agreed that counselling service was being rendered to students, just as Numale (2003) and Assoah (2004) also found out.

The finding of this study show that the counselling service forms the greater part of the activities of guidance programme in the schools, which is what it should be. The findings agree with Awabil (1996) and Adusei - Poku's (1996) who reported that counselling services provided in the senior secondary schools. Bondah (1996) also confirmed that counselling is seriously being provided in the schools. These findings are consistent with the purpose of counselling as assisting students understand themselves and become selfdirecting and self-realising individuals (Gibson and Mitchell, 1990); Shertzer and Stone, (1976). It is significant to note that counselling service seems to be the major and most popular service in the school; and that should not be surprising since counselling is at the core of guidance services.

It is observed from the data on orientation service that $76 \%$ of the students responded that orientation service is being provided.The data also indicate that out of 21 tutors who participated in the study, about $86 \%$ of them responded positively to the fact orientation service is delivered in the schools. All the coordinators responded that orientation service is delivered in the school. Majority of all the respondents responded "Yes" to that item that orientation is being provided in the senior secondary schools. Orientation programme is usually organized at the beginning of a new academic year, when all the tutors in the school are introduced to students. In view of that, it is not surprising that a great number of respondents gave a positive response. The findings of the study indicates that orientation service is provided in the senior secondary schools and it corroborates Assoah (2004) that orientation service is frequently offered to students in the school.

Upon interaction with the Guidance coordinators, the researcher detected from one of the schools covered in the study that, the coordinator is not a trained counsellor, but a revered minister. He teaches Religious and Moral Education in the school and because there is no coordinators he has been assigned the responsibility 
of acting as guidance coordinators. To him, he only provides counselling service alone in the school. The rest of the other service and guidance programme are not known to him. This fact may account for the one coordinators who responded negatively to all items on services with the exception of counselling and orientation. With orientation, the school organises it once a year for newly admitted students.

The data show, that students are made aware of the programme and that the coordinators organized them. The orientation programme were to assist students adapt to the school environment and to enable members of staff to be acquainted with individual students so that academic, social and personal help could be offered (Napier, 1972, cited in Oladele 2000)

Response from all the respondents shows that, the schools' authorities, in collaboration with the guidance coordinator, guidance committee members organised the orientation programme. All the tutors were involved in educating the students on roles they perform and what they expect of students. This is consistent with the guidance principle of team work and cooperation (Shertzer and Stone 1976).

The orientation programme have helped and exposed the students to classrooms, dormitories, administrative set- up rule and regulation governing student conduct and the use of school facilities like the library, bookshop and canteen. The data evaluation service indicates that students' responses to the evaluation service show that $34 \%$ said "Yes" and $61 \%$ said "No". $33 \%$ of tutors asserted to the availability of evaluation service while $61 \%$ said 'No". In the case of coordinators respondents, $83 \%$ responded 'Yes' and $17 \%$ responded "No" to the evaluation of guidance programmes.

The result from both students and tutors indicated a disappointing performance in this area when $61 \%$ of both students and tutors indicated that there was no evaluation service in the schools. Various reason may account for this level of performance. It is understandable for the students to show ignorance since the evaluation service is not of direct benefit to them.

Meanwhile $83 \%$ of the coordinators stated that they evaluate the programme but because of lack of time as a result of the heavy teaching load, they do it annually.

These results are in agreement to the findings of Amenyedzi (1997), which state that the availability of the evaluation service in the senior secondary schools was disappointed from the point of view of both students and tutors. Bondah (1996), also found out in his study that the evaluation service was ineffective in the senior secondary schools. However, the findings of Numale (2003) are not in agreement with the above researchers. Numale (2003) found out that the evaluation service is provided.

\section{Provision of Assistance}

All the three groups of respondents responded to the items on solving personal and academic problem. On solving personal problems, $31 \%$ of students indicated that the guidance services had helped them, while $91 \%$ of tutors and $100 \%$ of coordinators also indicated that they helped students solve personal problems. On academic problems $31 \%$ had solved their academic problems with the help of the guidance coordinators. The data from tutors and coordinators reveal that $86 \%$ out of $100 \%$ of coordinator who were involved in the study have helped students solve their academic problems. This means that students, tutors and coordinators agree that the guidance programme assist students in solving their personal and academic problems.

Table 2 : A distributive table assessing the various Assistance Sought by Students

\begin{tabular}{|l|l|l|}
\hline Type of assistance & Frequency & Percent \% \\
\hline Planning for higher education & 35 & $18.6 \%$ \\
\hline Assistance of how to study & 49 & $26.0 \%$ \\
\hline Planning for future career & 48 & $25.5 \%$ \\
\hline
\end{tabular}




\begin{tabular}{|l|l|l|}
\hline How to take down notes & 132 & $70.2 \%$ \\
\hline Selecting higher institutions & 64 & $34.0 \%$ \\
\hline Discussion programmes & 106 & $56.3 \%$ \\
\hline
\end{tabular}

\section{Source: Field data, Sackey, Bentil and Asiedu, (2018)}

On the issues of assistance sought by students the data reveals that only $19 \%$ sought the coordinators direct assistance concerning higher education. The number may seem too small but it is possible that students did not either know of the service or were sure to secure admission once they made good grade at the SSSCE examinations. $26 \%$ of students had benefited on how to study through the help of the guidance coordinators. It looks like, it is not all students who find it necessary to talk to the coordinators on these issues. With the planning for future career $26 \%$ of the students have been to the coordinators for such assistance. However, 35 of the students did not respond to this question. The reason may be they had not been to the coordinator before or they were not aware that the coordinator is capable of helping solve higher educational problems of students or they did not think they needed that type of service. The same reason could be assigned to the 22 students who responded "No" to the items. 70\% acquired skills of taking down notes through the help of coordinators and $34 \%$ had gone through selecting higher institution and $56 \%$ had discussed programme offered in higher institutions. From the students' responses to the types of assistance sought from the coordinators, which involved every student, there to be confirmation of Ackon's (1992) findings that students had a low perception of the coordinator's usefulness and guidance programme.

Table 3 : Descriptive statistics on Assistance provided by Tutors and Coordinators

\begin{tabular}{|l|lc|lc|}
\hline Types of assistance & \multicolumn{2}{|l|}{ Tutors Freq. } & \multicolumn{2}{|l|}{$\begin{array}{l}\text { Co'nator Freq. } \\
(\boldsymbol{\%})\end{array}$} \\
\hline Access to career information & 10 & 47.6 & 3 & 50 \\
\hline Solving relationship problems & 14 & 66.7 & 5 & 83.3 \\
\hline Overcoming examination anxiety & 14 & 66.7 & 4 & 66.7 \\
\hline
\end{tabular}

\section{Source: Field data, Sackey, Bentil and Asiedu, (2018)}

The data on if students have access to career information, as, indicate that about $48 \%$ of the tutors said that students get access to information about jobs through guidance programmes. The data show that the coordinators were split equally, so it is difficult to establish the true position of affairs. The same comment can be made on the responses from tutors since they were also almost split into two.

The question that arise, by the equal numbers of tutors and coordinators who responded 'Yes' and 'No' are (i) Is information about jobs available or provided in all the school? Or (ii) Are the 'Yes' responses coming from schools that have information on jobs, and so is accessible to students in those schools, while the 'No' responses emanated from schools without? If the answer to the two-question raised are 'No' and 'Yes' respectively, then it will be necessary for all schools to endeavour to build up a job information source and make it available and easily accessible to students.

With the item solving relationship problems, about $67 \%$ tutors responded that they help students to solve their relationship problems through guidance programmes. Eighty three percent of the coordinators responded positively to the items. This shows that, tutors and coordinators are doing well by helping students solve relationship problem.

the data also show about $67 \%$ of both tutors and coordinators responding that they help students to get over examination anxiety. It is interesting to observe that for both the tutors and coordinators, half of those who responded positively responded negatively. The reason may be that only schools who organized programmes to help students overcome examination anxiety responded to it. It is suggested that other schools should also include this in their schools' guidance programmes. 
The activities least performed were seeking funding for, and evaluating programmes. On funding, it may seem that guidance committees or coordinators did not see it as their responsibility to seek funding or relied solely on what the school authority could dole out to them. What is most disturbing is the near no evaluation of the programme. One wonders how programmes could run indefinitely without evaluation. How would programme implementers know whether they are succeeding or failing, identify strength and weakness and keep to good practice and institute connective measures without any form of evaluation?

The data indicate that the guidance committee in the schools help the schools to achieve their objectives ( $86 \%$ and $83 \%$ of tutors and coordinators respectively), and helps improve the schools' SSSCE examination performance ( $76 \%$ of tutors and $83 \%$ of coordinators). The data also indicate that about $86 \%$ of tutors and all coordinators responded that they have helped students to improve their results. The results of the study show the importance of the committees' work. They organized annual meeting to enable members of staff to be acquainted with individual students so that academic, social and personal help could be offered (Napier, 1972; cited in Oladele, 2000). The organization of programmes involved committee members and this is consistent with the guidance principle of team work and cooperation (Shertzer and Stone, 1976).

This is done with corroboration with the school authorities as preventive and therapeutic since the students' transition from the junior secondary schools (JSS) to Senior Secondary School (SHS) has its own challenges to overcome. Some of the challenges are inter-personal relationships, and include boy-girl relations, study habits, emotional stability and security.

Orientation service was seen as preventive so the first year students are given first-hand information about the consequences or outcomes of violating any of the school rules and regulation. This collaborates the popular saying "Prevention is better than cure". For instance, channels of communication are facilitated for students to contact the right "officer" in time of need. This has a great impact on students' life during their stay in the school and helps them to stay away from troubles as the rules and regulation of the school are made known to them during that programme. The findings of the study on orientation service is in consonance with Abukari (1996) and Adusei-Poku (1996) that orientation service was effectively provided. It also confirms Awabil (1996) and Bondah (1996) who found out that orientation service was being offered to students when they first arrive at school. According to the guidance coordinators and other members of staff, the organization of orientation had been the practice in the school. This affirmation is in line with the main purpose of orientation, that is, to ensure that students are emotionally secured and better adjusted in their new school environment (Oladele, 2000; Makinde, 1987)

\section{Difficulties and challenges}

The item," what difficulties does your school's guidance programme face?" was asked of all respondents students, tutors, and coordinators. They were asked to tick as many of the suggested responses as possible.

Table 4 : Distributive table indicating difficulties the Guidance coordinators faces in rendering of the Guidance services in the various selected Schools

\begin{tabular}{|l|cc|cc|cr|}
\hline Type & \multicolumn{2}{|c|}{$\begin{array}{c}\text { Student Freq. } \\
\text { \% }\end{array}$} & \multicolumn{2}{|c|}{ Tutors Freq. } & \multicolumn{2}{|l|}{$\begin{array}{l}\text { Coordinators } \\
\text { Freq. }\end{array}$} \\
\hline Lack of counselling facilities & 197 & $83.3 \%$ & 13 & $61.9 \%$ & 4 & $66.7 \%$ \\
\hline Lack of office accommodation & 197 & $83.8 \%$ & 16 & $76.2 \%$ & 5 & $83.3 \%$ \\
\hline No confidentiality during counselling & 112 & $47.6 \%$ & 16 & $76.2 \%$ & 5 & $83.3 \%$ \\
\hline Coordinator always busy teaching & 141 & $60.0 \%$ & 15 & $71.4 \%$ & 5 & $83.3 \%$ \\
\hline Coordinator not available always & 118 & $50.2 \%$ & 17 & $81.0 \%$ & 4 & $66.7 \%$ \\
\hline
\end{tabular}

\section{Source: Field data, Sackey, Bentil and Asiedu, (2018)}

The results indicate that $62 \%$ of tutors, $67 \%$ of coordinators and $84 \%$ of students picked lack of counselling facilities. Majority of the respondents, $76 \%$ of tutors, $84 \%$ coordinators and $84 \%$ students said they lack office accommodation about $76 \%$ of tutors and $84 \%$ of coordinators said there is no confidentiality in counselling because of lack of office accommodation for the coordinator. $50 \%$ of the students, $81 \%$ of the tutors and about $67 \%$ of coordinators responded that the coordinators were not available when students want to see them. This means that it is difficult to see the coordinators whenever they wanted to see them. $60 \%$ 
students, $71 \%$ of tutors and $84 \%$ of the coordinators mentioned that because of the heavy teaching load of coordinators, students do not see them when they need them. From the table it is significant that all the three groups of respondents stated that the coordinators are always busy teaching and that students do not see the coordinators when they need them, lack of counselling facilities and lack of office accommodation as difficulties facing the guidance programme in their schools.

\section{Findings}

The findings were made from the study:

The study revealed that Pupil's Appraisal service, orientation service, counselling services, placement services, information service and consultation service are provided in the senior secondary school. It was the finding of the study that Students and tutors were divided in option on the level of provision of the consultation service. The study further revealed that, there was no evaluation service in the schools.

Guidance programme had benefited students by helping solve their academic and personal problems. Furthermore it was found out that, both internal examination and external (SSSCE) examination results have improved drastically among the students.

Guidance programmes have helped them to find out the programmes offered in higher institution and introduced them to career opportunities in life. Almost all the guidance coordinators complained that they did not have enough time to do effective guidance work because of the heavy teaching load they have been assigned to.

Almost all guidance coordinators did not have offices and other facilities for counselling.

\section{Conclusions}

It may be concluded that the guidance services are encouraging and beneficial to students and students, tutors and coordinators appreciate them. However, some of the services are not being adequately provided to meet all the objectives of the programme.

The results of this study agree with earlier researches cited. With the exception of evaluation service, which is not very satisfactorily provided, the rest are being provided in the senior secondary schools in the Central Region. The services are also beset with some challenges and constraints. 1. Lack of counselling facilities and 2. Lack of office accommodation is difficulties facing the guidance programme in their schools.

\section{Recommendations}

In the light of the findings and observations and for the improvement of the guidance services in schools the following recommendations have been made:

1. Heads of institutions should re-examine the issue of heavy teaching schedules of guidance coordinators and assign coordinators the GES approved levels.

2. Serious efforts must be made by school administrators to provide coordinators with at least, fairly furnished offices for individual counselling.

3. All Guidance Co-ordinators must plan guidance programmes that meet the needs of their students.

4. Leadership roles in the school's guidance programme must also be provided by the coordinators.

5. The Ghana Education Service should appoint full-time coordinators to the schools.

6. In - service training should be organised for coordinators from time to time by the Ghana Education Service and heads of schools.

7. Coordinators should plan and evaluate their activities.

8. The Ghana Education Service and Government should make budget allocations for guidance programmes in schools.

9. The Ghana Education Service should make it a policy and mandatory for all heads of senior secondary schools to integrate guidance programmes into the normal academic calendar.

10. All stakeholders in education stop paying lip-service to the need for guidance service and provide all the support for guidance service. 
It is hoped that if these recommendation are implemented and qualified counsellors are posted to all schools, there will be remarkable improvement in guidance activities, otherwise we have to contend ourselves with what Fontana (1988) cited in Amenyedzi (1977) has concluded, that "However much we may be in favour of specialist counsellors, it is probable that the counselling role will still largely be left to the ordinary teacher for the foreseeable future".

\section{Areas for further research}

The present study is limited in scope because only an aspect could have been covered by such a study. In view of this, is it is recommended that similar studies should be undertaken in other Region in order to have a nationwide evaluation of guidance services being provided in the various Schools in the country.

Students recognised and perceived guidance services as important and useful, it will also be necessary to research into the guidance needs of students in senior secondary schools so as to effect a comprehensive guidance programmes to meet their needs.

\section{References}

[1] Abukari, A. (1996). Investigation into Guidance and Counselling Programmes in TSS and SSS in Tamale Municipality (Unpublished B. Ed Long Essay, University of Cape Coast).

[2] Ackom, P. E. (1992). Secondary School Students' Perception of Guidance Co-ordinators. A Study in the Western Region of Ghana. (Unpublished M.Ed. Thesis, UCC.)

[3] Adusei - Poku, K. (1996). An Evaluation of the role Guidance Co-ordinators in some Selected Senior Secondary School in Accra Urban, Ghana. Unpublished B. Ed. (Psychology) Research Project. Faculty of Education, University of Cape Coast, Ghana.

[4] Amenyedzi, W.F.K. (1997). The Teaching of Sex Education in the Junior Secondary School - A case study of Ketu Junior Secondary School - Dzodze. (Unpublished project Work, UCC.)

[5] Amenyedzi, W. F. K. (1997). An Evaluation of the Guidance Programmes of Senior Secondary Schools in the Ketu and Keta Districts, (Unpublished M. Ed. Thesis, UCC)

[6] Archer, F. K. (1989) Guidance and Counselling for Schools and Colleges (Unpublished)

[7] Assoah, S. K. (2004) A survey of Guidance Service in Senior Secondary Schools In Some Selected Districts in the Western Region of Ghana. (Unpublished M. Phil thesis, UCC)

[8] Awabil, G. (1996). Investigation of Guidance Programmes in Junior and Senior Secondary Schools in the Bulsa District of Ghana. (Unpublished B. Ed. (Psychology Research Project, Faculty of Education, University of Cape Coast, Ghana.)

[9] Bedu - Addo, P. K. A. (2002). Guidance and counselling “unmasked” (2 ${ }^{\text {nd }}$ ed) Accra: Type Company Limited, Blocher D. (199). The Professional Counsellor. New York: Macmillan.

[10] Bondah, E. K. (1996). An Evaluative Study Guidance and Counselling Programmes in Selected Senior Secondary Schools in the Assin District of Ghana. (Unpublished B. Ed. (Psychology) Research Project. Faculty of Education, UCC)

[11] Capuzzi, D., \& Gross, D. R. (1997) Introduction to group counselling ( $2^{\text {nd }}$ ed) Denver: Love publishing

[12] Cohen, I. \& Manion L (1991) Research Methods in Education (3 $\left.{ }^{\text {rd }} \mathrm{ed}\right)$ New York: Routledge, Champman and Hall Inc

[13] Cohen, I. Manion L., \& Morrion K. (2003) Research Methods. (5 ${ }^{\text {th }}$ d) New York: Routledge, Champman and Hall Inc

[14] Essuman, J. K. (1999). The History of Guidance and Counselling in Ghana. Ife: Psychologia 2 (2), 72-88)

[15] Fraenkel, J. \& Wallen N. E. (1990). How to Design and Evaluate Research in Education (2 ${ }^{\text {nd }}$ ed) New York: McGraw-Hill, Inc.

[16] Fraenkel, J. \& Wallen N. E. (2000). How to Design and Evaluate Research in Education ( $4^{\text {th }}$ ed) Boston: McGraw-Hill, Inc.

[17] Gay L. R. (1992). Educational Research: competencies for Analysis Application. Columbus, Ohio: Charles E. Merril Publishing Co.

[18] Gibson, R. L. \& Mitchell, M. H. (1990). Introduction to Guidance. New York: Macmillan Publishers. 
[19] Gibson, R. L. \& Mitchell, M. H. (1990). Introduction to Counselling and Guidance (3 ${ }^{\text {rd }}$ ed) New York: Macmillan Publishing Company.

[20] Ipaye, T. (1983). Guidance and Counselling Practices. Ile - Ife: University of Ife Press.

[21] Ipaye, T. (1986). Roles and Functions of Counsellors in Nigerian Schools. The Nigerian Journal of Guidance Counselling Vol. 1. Pg. 87-105.

[22] Kankam, G. \& Onivehu, A O. (2000). Principle and Practice of Guidance and Counselling. Accra: K” N" A. B. Ltd.

[23] Makinde, O. (1984). Fundamentals of Guidance and Counselling London: Macmillan Publishers.

[24] Ngama L. O. (1990). The Effectiveness of Evaluating the Guidance Programme in Onitsha Education Zone. (Unpublished M. Ed. Thesis, University of Nigeria Nsukka)

[25] Numale, M. K., (2003) Evaluation of Guidance and counselling services in the Senior Secondary Schools in Upper West Region of Ghana. (Unpublished M. Phil Thesis, UCC)

[26] Ocansey, S. M. (1992). Guidance and Counselling as Practised in Selected Schools in Cape Coast. (Unpublished M. Ed. Thesis, UCC)

[27] Okon, S. E. (1984). Guidance for the 6-3-3-4- system of Education. Zaria:. Institute of Education.

[28] Okoye, N. N., Adejumo, D., \& Achebe, C. (1990) Fundamentals of guidance and counselling, Ibadan Heinemann Educational Books (Nigeria) Ltd.

[29] Oladele J. O. (2000). Guidance and Counselling, Lagos: Johns-Lad Publishers Ltd.

[30] Sarrantakos, S (1988). Social Research ( $2^{\text {nd }}$ ed) Houndmils: Macmillan Press Ltd.

[31] Shertzer, B. \& Stone, C. (1976). Fundamentals of Guidance. Boston: Hounghton Mifflin.

[32] Shertzer, B. \& Stone, C. (1980). Fundamentals of Counselling ( $3^{\text {rd }}$ Ed.) Boston: Houghton Mifflin http://www.poly.edu/counselling/services/index.php 